\title{
Data Security System login With MD5 Algorithms in Applications deskresy.com
}

\author{
Rahmat Ferdiansyah ${ }^{1}$, Paska Marto Hasugian ${ }^{2}$ \\ ${ }^{1.2}$ Informatics Engineering Study Program, STMIK Pelita Nusantara, J1. Iskandar Muda 1 \\ Medan, North Sumatra, Indonesia 20154 \\ E-mail:rahmatfe9@gmail.com,paskamarto86@gmail.com
}

\begin{abstract}
Cryptography is a technique of data security by processing the data (plaintext) using an encryption method so that the the data can not be read directly, especially by unauthorized parties. Confidential Data and information need to get serious attention considering the value of information contained in it so that procedures are needed to hide the messages stored Therein. Data security Becomes very important at this time, Because for every decision or policy making must be based on the data. Md5 is a substitute for MD4, MD5 is one of the most Widely used one-way hash functions, MD5 processes the input into blocks of 512 bits, the output of md5 is 128 bits and has a fixed length. MD5 algorithm is Widely used for various purposes in making security in applications, it is Often used to help login validation on the use of passwords stored in the database system.
\end{abstract}

Keywords - Cryptography, Data Security, .md5.

\section{Introduction}

Cryptography is one technique of data security by means of process data and process an encryption method so that the data can not be read directly, especially by unauthorized parties. Encryption process uses an algorithm commonly used in cryptography. There are many cryptographic algorithms that can be implemented for the encryption for data and information that we had a safe.

Computer security is a preventive activity of crimes using as a medium. Security needed include physical security (infrastructure danpendukung server room), access security (human users), data security (viruses and data theft) and the security of the computer's operating system. In building a computer security should consider confidentialy, integrity, authentication, non-repudiation and availability.[1] Data and information become the target of attacks by parties who are not responsible so it is necessary to maintain the integrity of data and information.[2]

Deskresy.com is a container or a place used to promote creativity in a village in the form of information information about the product or the development of a village into the Internet, the website is also useful to be able to build the economy of the village. This website consists of several parts such as the home menu, login menu, and some other villages keratifitas information.

weakness that often occurs within a website is the security of user data, password data in place must be guarded or protected and confidential.[3]data security factors are very important and must be considered.

MD5 algorithm is a message-digest algorithm invented by Professor Ronald Rivest of the Massachusetts Institute of Technology (MIT). When the performance of the predecessor MD4 MD5 algorithm which started unsafe, then MD5 was built in 1991 as the MD4 algorithm. MD5 hash along a 128-bit (16-byte), message digest .md5 displayed in 32-digit hexadecimal number.[4]MD5 has been utilized in various security applications and MD5 are also commonly used for testing the integrity of the data. MD5 algorithm is widely used for various purposes dalma create security on applications, it is often used to help falidasi login to the system using the password stored in the database. In order to add value to the security of a system.

\section{Theory}

\section{1 cryptography}

Based on the words that form of "Crypto" which means secret, and "graphy", meaning writing could mean that cryptography is secret writing or by word Laian post whose secret nature such that only those eligible are able to translate his writings. William Stallings defines cryptography as "the art and science of keeping messages secure".[5]

\section{a. Terminology Cryptography}

Keripstografi terminology is the process of taking the message into code, through a message, then the sender and recipient, the encryption and description, and others - others, PM is the data or information that can be read and understood its meaning. Another name for the message is called plaintext or clear text (cleartext). So that the message is not understood by the other party in such a way dibat sehinggatidak need not be 
understood. An encrypted message is called ciphertext or cryptogram. Ciphertext must be transformed back into plainteks. Sender is an entity that sends a message. Receiver (receiver) that receives the message. Entities can be people, machines, credit cards and sebagainya.Proses encrypt the plaintext into chiperteks called encryption (encryption). whereas the process of restoring the ciphertext into plaintext is called decryption (decryption). Also called cipher cryptographic algorithm that rules for enchipering and dechipering, or a mathematical function used for encryption and decryption. Cryptanalysis (cryptanalysis) is the science and art to solve chiperteks into plaintext without knowing the given key. The culprit is called cryptanalyst. Cryptology (cryptology) is the study of cryptography and cryptanalysis.[6]Cryptography is widely used to maintain the aspect of information security. One function of cryptography that can ensure the integrity of data that is downloaded from the Internet MD5 hash function.[7]

\section{2 algorithms .md5}

MD5 is a one-way hash function, which mengubaharbitrary-length message into a fixed output of 128 bits. Inputblok divided into several blocks of 512 bits (sixteen 32-bitkata-word, denoted by $\mathrm{Xj}$, where $\mathrm{j}$ indicates the number of blocks). Merekadiproses separately with the highest priority X0. Inputpesan required when the length of the message tidakkongruen with 512.[8]

Modifications to any changes to the original data, even if only one byte is modified, will make a significant difference in the value of MD5. Very difficult to find documents that have the same MD5 value.[9]

\section{a. Extra bits booster}

The first process is done is add a message with the number of bits booster so that the message length (in bits) is congruent to 448 modulo 512. First of all, the message was given extra length becomes such that $\mathrm{k}$ bits, diamana $\mathrm{k}=512 \mathrm{~N}-64$ bit.[10]

\section{b. Extra Long plaintext}

After the addition of bits wedge then followed by increasing the length of the original message followed by the addition of 64 bits and 0 so that even 512 bits.

\section{c. initialization Buffer}

Initialization phase has some kind on the specified initialization .md5 example is $\mathrm{A}=01,234,567, \mathrm{~B}=$ 89ABCDEF, $\mathrm{C}=$ FEDCBA98, $\mathrm{D}=76.54321$ million.

d. processing $\cdot \mathbf{m d 5}$

The function fF, FG, FH, and fI is a function to manipulate the inputs a, b, c, and d with a 32-bit size.

\section{Methodology}

In this study, using a model of a flow chart, which measures a structured decreased to obtain the intended results. The results of the research applied to the system.

\subsection{Analysis}

The data analysis was interpreted as an attempt to process the data into information, so that the characteristics or properties of the data can be easily understood and useful to address issues relating dengankegiatan research.[11] Examples of data records in the table below:

Table 1.

Record Username

\begin{tabular}{|l|l|l|}
\hline id & username & password \\
\hline 1 & Grace & 12345 \\
\hline
\end{tabular}

record example username $=$ grace, then is converted into hexa-decimal as follows:

a. Extra bits booster

1) Plaintext $=$ grace

2) Hexa $=72617461686 \mathrm{D}$

3) Plaintext $=48$ bits long.

4) The bit length booster $=($ modulo 448512$)-48=400$

01110010011000010110100001101101

01100001011101001000000000000000

00000000000000000000000000000000

00000000000000000000000000000000

00000000000000000000000000000000

00000000000000000000000000000000

00000000000000000000000000000000

00000000000000000000000000000000

00000000000000000000000000000000

00000000000000000000000000000000 
00000000000000000000000000000000 00000000000000000000000000000000 00000000000000000000000000000000 00000000000000000000000000000000

5) Thus, the plaintext $(\mathrm{P})=$

$7261686 \mathrm{D} 6174310000000000000000000000000000000000000000000000000000$ 0000000000000000000000000000000000000000000000

b. Extra Long plaintext

After the addition of a booster bits in plaintext is then followed by the addition of the original message length and followed by the addition of a 64 bit number 0 so that even amount to 512 bit plaintext The steps are as the following additions.

1) Pawal (Hexa) $=72617461686 \mathrm{D}$

2) Pawal (Binary) $=011100100110000101101000011011010110000101110100$

3) The length of the original message $=48$ bits

4) Thus, $\mathrm{P}=726168$ 6D 61743100000000000000000000000000000000000000000000 $00000000000000000000000000000000 \quad 000000000000000000000048000000$

c. Buffer initialization message digest

Initialization phase for some versions of MD5 has an initial value different from some initialization is specified, $\mathrm{A}=01,234,567, \mathrm{~B}=89 \mathrm{ABCDEF}, \mathrm{C}=\mathrm{FEDCBA98}, \mathrm{D}=76.54321$ million.

d. The processing of .md5

The function $\mathrm{fF}, \mathrm{FG}, \mathrm{FH}$, and $\mathrm{fI}$ is a function to manipulate the inputs a, b, c, and d with a 32-bit size.

Then the value of $\mathrm{T}$ [i] can be seen in the table below. These are organized by function $232 \mathrm{x}$ abs ( $\sin (\mathrm{i})$ ), $\mathrm{i}$ in radians.

The equation for the MD5 process are:

Round 1: $\mathrm{a}=\mathrm{b}+((\mathrm{a}+\mathrm{F}(\mathrm{b}, \mathrm{c}, \mathrm{d})+\mathrm{X}[\mathrm{k}]+\mathrm{T}[\mathrm{i}])<<<\mathrm{s})$

Functions used at the input $F(b, c, d)=(b c) \otimes((\sim b) d)$

FF (a, b, c, d, x [0], 0xD76AA478)

FF: $\mathrm{a}=01234567, \mathrm{~b}=89 \mathrm{abcdef}, \mathrm{c}=$ fedcba98, $\mathrm{d}=76.54321$ million, $\mathrm{x} 0=6 \mathrm{~d} 686172$,

$\mathrm{s}=7, \mathrm{Ti}=\mathrm{d} 76 \mathrm{aa} 478$

$\mathrm{F}=$ (89abcdef fedcba98) $\otimes((\sim 89 a b c d e f) 76.54321$ million $)$

$=(88888888) \otimes(76543210)$

$=$ fedcba98

$\mathrm{A}+\mathrm{F}(\mathrm{b}, \mathrm{c}, \mathrm{d})+\mathrm{x} 0+\mathrm{ti}=01,234,567+$ fedcba9 $9+6 \mathrm{~d} 686172+\mathrm{d} 76 \mathrm{aa} 478$

$144 \mathrm{~d} 305 \mathrm{e} 9 \mathrm{mod}=232$

$=44 \mathrm{~d} 305 \mathrm{e} 9=01000100110100110000010111101001$

$\operatorname{CLSS}(\mathrm{a}+\mathrm{F}(\mathrm{b}, \mathrm{c}, \mathrm{d})+\mathrm{x} 0+\mathrm{Ti})$

CLS7 $(44 \mathrm{~d} 305 \mathrm{e} 9)=11011001111110001101110000010010$

$=9 \mathrm{~d} 6 \mathrm{ba} 622$

$=\mathrm{B}+\mathrm{d} 9 \mathrm{f} 8 \mathrm{dc} 12$

$=(89 \mathrm{abcdef}+\mathrm{d} 9 \mathrm{f} 8 \mathrm{dc} 12) \bmod 232$

$=13$ eed 568

Ciphertext $=\mathrm{ABCD}=$ af2a4c9d 9d6ba622 4c4956ec 13 eed568.

The final output of the encryption text "grace" to use the MD5 algorithm is "af2a4c9d4c4956ec9d6ba62213eed568".

\subsection{Design}

System design using modeling (modeling) is the process of designing software before coding (coding). Make a model of a complex system is very important because we can not conceive of such a system as a whole. analysis is performed by modeling problems in bentukdiagram-diagramUML.[12]

a. Use Case Diagram

Use Case diagram is a model for the behavior (behavior) information system that will be created.[13]Use Case diagram below illustrates how users interact with the system yangakandibuat.[14]

b. Activity Diagram

Activity diagrams can be used to explain the business and operational workflow step-by-step from the components of a system. Activity diagram shows the overall flow of control.[14]

c. sequence Diagram 
A presentation of the behavior that is structured as a series of pilot measures from time to time. Sequence diagrams used to describe a scenario or series of steps undertaken in response to an event to generate a specific output.[14]

d. Class Diagram

Class diagram is a type of diagram that is used to map a particular system by modeling the structure of classes, attributes, operations and relationships between components and objects.[14]

\section{Implementation}

To implement a security systemData logged on using algorithms md5 deskresy.com applications that have been built using web programming languages. Web editor used are Dreamweaver, Deramweaver an output of Adobe Systems software used for building and designing a website.[15]This system needs to run the software as it needs danperangkat hard. The implementation results of this study are as follows:

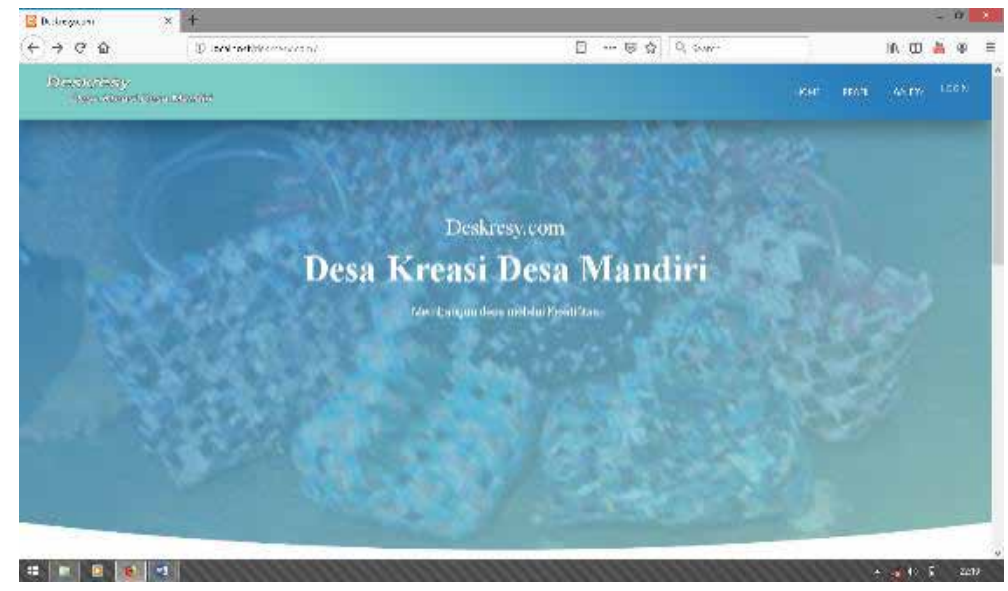

Figure 1. The initial view website

In Figure 1 above is an example of the application deskresy.com home menu, there are several menu including home menu, profile, gallery and login.

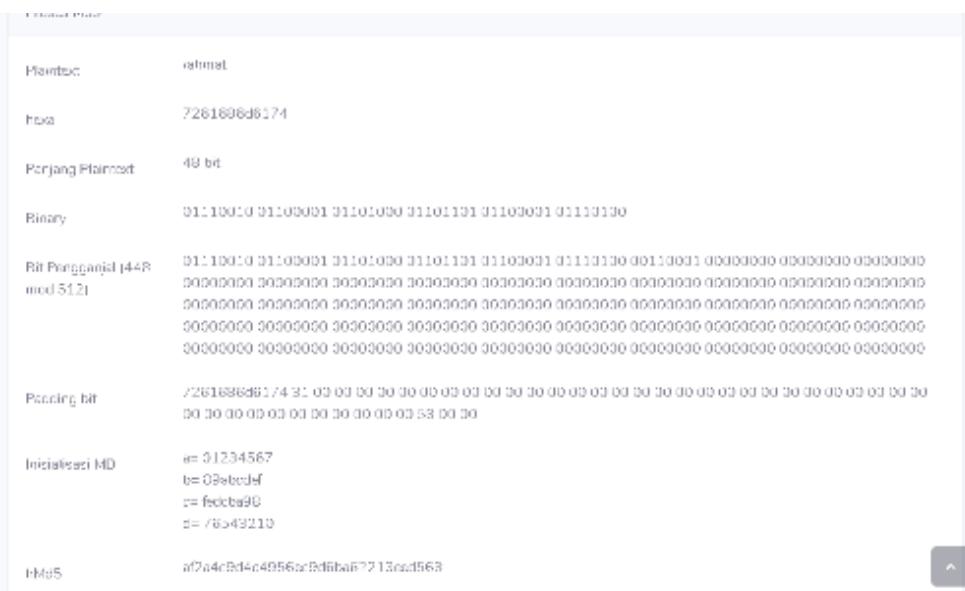

Figure 2. Simulation Display Encryption .md5

.Md5 encryption simulation page is the page that is used to determine the process of data encryption to be encrypted characters.

\section{Conclusion}

Based on the research and analysis on a chapter - the last chapter, it was concluded as follows:

a. $\quad$ Md5 security by using the algorithm can improve the security of the system, in use .md5 processing and storing the data of the same size. 
b. Md5 process data in the amount of 512 bits to generate a unique character that can not be read normally, characters that produced a 32 characters.

\section{Reference}

[1] D. Atmodjo, “Peningkatan Keamanan Data dengan Metode Cropping Selection Pseudorandom," vol. 4, no. 3, pp. 132-138, 2016.

[2] D. M. Khairina, "Analisis Keamanan Sistem Login," J. Inform. Mulawarman, vol. 6, no. 2, pp. 64-67, 2011.

[3] Inayatullah, "Analisis Penerapan Algoritma MD5 Untuk Pengamanan Password,"J. Algoritm., vol. 3, no. 3, pp. 15, 2007.

[4] A. Pribadi and K. Kunci, "Perancangan Keamanan Sistem Login Aplikasi Multiuser Dengan Algoritma M essage Digest 5 (Md5)," Pelita Inform. Budi Darma Pelita Inform. Budi Darma Pelita Inform. Budi Darma, vol. 8, no. 2, p. 4, 2014.

[5] D. Darius, Kriptografi Keamanan Data dan Komunikasi. 2006.

[6] M. Natsir, "Pengembangan Prototype Sistem Kriptografi UntukEnkripsi Dan Dekripsi Data Office Menggunakan Metode Blowfish Dengan Bahasa Pemrograman Java,"J. Sist. Inf., vol. 6, no. 2, pp. 87-105, 2016.

[7] P. Informatika et al., "Perancangan Aplikasi Untuk Memeriksa Keaslian Data Yang Telah Didownload Menggunakan Algoritma Message Digest 5 (Md5)," Pelita Inform. Budi Darma, vol. 5, no. 3, pp. 172-177, 2014.

[8] K. Shahbazi, M. Eshghi, and R. Faghih Mirzaee, "Design and implementation of an ASIP -based cryptography processor for AES, IDEA, and MD5," Eng. Sci. Technol. an Int. J., vol. 20, no. 4, pp. 1308-1317, 2017.

[9] Y. Tian, K. Zhang, P. Wang, Y. Zhang, and J. Yang, "Add 'salt' MD5 algorithm's FPGA implementation," Procedia Comput. Sci., vol. 131, pp. 255-260, 2018.

[10] M. ir.Yusuf Kurniawan, Kriptografi Keamanan internet dan Jaringan komputer. 2018.

[11] Y. Apridiansyah and M. H. Rifqo, "STUDI MENGGUNAKAN ALGORITMA MESSAGE DIGEST 5 Studi Kasus : Fakultas Teknik Universitas Muhammadiyah Bengkulu," Nasional, vol. II, no. September, pp. 107-114, 2015.

[12] I. Akil, "Rekayasa Perangkat Lunak Dengan Model Unified Process Studi Kasus: Sistem Informasi Journal," $J$. Pilar Nusa Mandiri, vol. 12, no. 1, p. 11, 2016.

[13] m. salahuddi. rosa a.s, Rekayasa Perangkat Lunak. 2013.

[14] G. Windu Gata, "Pemodelan UML sistem informasi Monitoring Penjualan dan stok barang,"Pemodelan Uml Sist. Inf. Monit. Penjualan Dan Stok Barang (Studi Kasus Distro Zhezha Pontianak), vol. IV, no. 2, pp. 107-116, 2016.

[15] muhammad sadeli, Aplikasi Bisnis dengan php dan mysql. palembang: maxicom, 2014. 